\title{
Pembuatan Aplikasi Memantau Lokasi Anak Berbasis Android Menggunakan Location Based Service
}

\author{
Hendra Pria Utama ${ }^{1)}$, Oky Dwi Nurhayati ${ }^{2)}$, Ike Pertiwi Windasari ${ }^{2)}$ \\ Program Studi Sistem Komputer, Fakultas Teknik, Universitas Diponegoro \\ Jalan Prof. Sudharto, Tembalang, Semarang, Indonesia
}

\begin{abstract}
Abstrak - Pada era global seperti sekarang ini perkembangan teknologi sangat pesat terutama pada smartphone. Perkembangan teknologi smartphone yang begitu cepat menghasilkan dampak positif bagi manusia. Dampak positif tersebut antara lain kecepatan, kemudahan akses, dan kenyamanan dalam melakukan aktivitas sehari-hari. Sudah banyak aplikasi pada smartphone yang dibuat guna mempermudah aktivitas sehari-hari manusia, contohnya aplikasi menetukan letak lokasi pengguna. Dengan adanya aplikasi menentukan letak lokasi pengguna, pengguna dapat dengan mudah menentukan letak lokasi diri sendiri ataupun orang lain, seperti misalnya lokasi anak. Sering kali anak membolos sekolah dan keluar malam tanpa sepengetahuan orang tua mereka. Berdasarkan permasalahan terseut dibangun aplikasi memantau lokasi anak berbasis mobile guna memudahkan para orang tua memantau lokasi anakanak mereka.

Metode penelitian yang digunakan adalah SDLC (Software Development Life Cycle) dengan teknik waterfall. Aplikasi memantau lokasi anak ini berbasis android menggunakan bahasa pemrograman java, database MySQL, serta Location Based Service (LBS) sebagai penunjuk lokasi anak. Untuk metode pengujian aplikasi menggunakan metode Black Box Testing.

Hasil Black Box Testing dari aplikasi memantau lokasi anak berbasis android menggunakan LBS ini menunjukan bahwa semua fungsi yang terdapat pada aplikasi ini telah berhasil berjalan sesuai fungsinya.
\end{abstract}

Kata Kunci : Android, MySQL, Java, Location Based Service (LBS), SDLC.

\section{PENDAHULUAN}

$\mathrm{R}$ emaja adalah masa peralihan dari anak-anak ke dewasa. Pada masa remaja merupakan masa dimana untuk mencari pola hidup yang paling sesuai untuk dirinya. Seringkali pada masa ini banyak melakukan kesalahan-kesalahan yang menimbulkan kekhawatiran serta perasaan yang tidak menyenangkan bagi lingkungannya. Kesalahan-kesalahan remaja yang menimbulkan kekesalan pada lingkungan inilah yang sering disebut sebagai kenakalan remaja.
Salah satu faktor yang melatar belakangi kenakalan remaja antara lain yaitu, faktor eksternal. Contoh faktor eksternal adalah kurangnya perhatian dari orang tua. Keluarga merupakan unit social terkecil yang memberikan fondasi primer bagi perkembangan anak. Karena itu baik-buruknya struktur keluarga memberikan pengaruh baik atau buruknya pertumbuhan keperibadian anak. Salah satu contoh kenakalan remaja adalah bolos sekolah dan sering keluar malam.

Perkembangan teknologi semakin pesat pada era sekarang ini. Salah satu teknologo yang tidak bias lepas dari masyarakat saat ini adalah teknologo komunikasi menggunakan telepon pintar atau lebih dikenal dengan nama smartphone. Smartphone memiliki beberapa fitur diantaranya kamera, internet, dan Global Positioning System(GPS) termasuk teknologi LBS (Location Based Service). Location-Based Service (LBS) adalah sebuah service untuk memberikan informasi sesuai lokasi pengguna berada, contohnya seperti menunjukan lokasi terdekat dari pengguna, seperti SPBU, masjid, ATM. Location-Based Service memanfaatkan GPS dalam penaplikasiannya. LBS juga dapat diggunakan untuk menentukan lokasi pengguna.

Berdasarkan uraian diatas dan penelitian yang sudah ada, maka penulis tertarik untuk mengembangkan aplikasi tugas akhir dengan judul "Aplikasi Memantau Lokasi Anak Berbasis Android Menggunakan Location Based Service (LBS)". Dengan adanya aplikasi ini diharapkan dapat membantu orang tua dalam mengawasi anakanaknya.

Tujuan dari tugas akhir ini adalah untuk membuat aplikasi location based service (LBS) yang menampilkan lokasi anak yang dapat diakses melalui perangkat bergerak. Untuk menghindari pembahasan yang meluas maka dalam tugas akhir ini ditetapkan batasan-batasan masalah dengan hal-hal sebagai berikut :

1. Aplikasi ini dibangun untuk pengguna smartphone Android.

2. Aplikasi ini berjalan pada Android versi JellyBean 4.3 sampai Lolipop 4.5. 
3. Aplikasi ini dibangun untuk siswa SD sampai SMA dan para orang tua.

4. Aplikasi yang dibangun membutuhkan koneksi internet dan GPS.

5. Data yang digunakan bukan data sebenarnya (dummy).

6. Posisi yang ditunjukan oleh suatu GPS mempunyai faktor kesalahan.

7. Penelitian ini bermaksud merancang dan membuat aplikasi yang dapat menampilkan lokasi keluarga terutama anak tanpa membahas kecurangan-kecurangan yang dilakukan oleh anak.

\section{DASAR TEORI}

\section{A. Java}

Java merupakan bahasa pemrograman objek murni karena semua kode programnya dibungkus dalam kelas. Java berdiri diatas sebuah mesin interpreter yang diberi nama Java Virtual Machine (JVM). JVM inilah yang akan membaca bytecode dalam file .class dari suatu program sebagai representasi langsung program yang berisi bahasa mesin. Oleh karena itu bahasa java disebut sebagai bahasa pemrograman yang portable karena dapat dijalankan pada berbagai sistem operasi, asalkan pada sistem operasi tersebut terdapat JVM ${ }^{[7]}$.

\section{B. Location Based Service (LBS)}

Location Based Service atau LBS adalah salah satu bentuk layanan yang didasarkan pada posisi pelanggan berada di saat ini. Kadangkala, user/pelanggan sendiri tidak mengetahui di mana dia berada. Oleh karena itu sistem yang akan bekerja untuk membantu pelanggan menentukan posisinya saat ini. Selanjutnya setelah posisi tersebut diketahui, data tersebut dapat digunakan untuk memenuhi kebutuhan pelanggan dan memungkinkan pelanggan untuk mengakses segala informasi yang terkait dengan posisinya saat ini melauli GPS ${ }^{[8]}$.

\section{Global Positioning System (GPS)}

GPS adalah singkatan dari Global Positioning System, yang merupakan sistem navigasi dengan menggunakan teknologi satelit yang dapat menerima sinyal dari satelit. Sistem ini menggunakan 24 satelit yang mengirimkan sinyal gelombang mikro ke bumi. Sinyal ini diterima oleh alat penerima (receiver) di permukaan, dimana GPS receiver ini akan mengumpulkan informasi dari satelit GPS, seperti latitude dan longitude.

Posisi yang ditunjukkan oleh suatu GPS mempunyai faktor kesalahan atau juga disebut tingkat akurasi. Sebagai contoh suatu alat GPS menunjukkan titik koordinat dengan tingkat akurasi 5 meter, itu berarti posisi pengguna bisa berada dalam range radius 5 meter dari titik yang ditunjukkan tersebut. Ada beberapa hal yang mempengaruhi tingkat akurasi tersebut, antara lain:

1. Kesalahan Multipath. Terjadi karena sinyal satelit membentur permukaan keras (seperti bangunan atau tebing) sebelum mencapai GPS receiver. Hal tersebut bisa menyebabkan terjadinya delay sehingga perhitungan jarak menjadi tidak akurat.

2. Buruknya Sinyal Satelit. Hal tersebut dikarenakan posisi dari satelit yang terus bergerak atau bisa juga disebabkan faktor penghalang lain seperti pohon, gedung bertingkat, dan sebagainya. ${ }^{[6]}$

D. MySQL

Basisdata adalah kumpulan informasi yang disimpan di dalam computer secara sistematis sehingga dapat diperkisa menggunakan suatu program computer untuk memperoleh informasi dari basis data tersebut.

Database Management System atau DBMS merupakan suatu perangkat lunak yang digunakan untuk membuat, memelihara, mengontrol, dan mengakses basisdata secara praktis dan efisien. Sedangkan RDBMS atau Relationship DBMS merupakan salah satu DBMS yang mendukung adanya Relasi atau hubungan antar tabel.

MySQL adalah sebuah perangkat lunak sistem manajemen basis data SQL DBMS yang multithread, multi-user, dengan sekitar 6 juta instalasi di seluruh dunia. ${ }^{[9]}$

\section{E. $\quad P H P$}

PHP dibangun dari scripts yang ditulis secara plaintext. PHP Interpreter adalah bagian dari perangkat lunak yang ada pada Web Server, yang membaca file tersebut dan mengartikannya, memberikan keluaran HTML dan petunjuk mengenai bagaimana perilaku yang ada maupun menginterpretasikan masukan dari pengguna. ${ }^{[3]}$

PHP harus ditulis diantara tag $<$ ? dan ?>, <? php dan ?>, $<$ script language="php" $>$ dan $</$ script $>$, atau $<\%$ dan \%>. Setiap perintah pada PHP diakhiri dengan tanda ; (semicolon atau titik koma). PHP merupakan bahasa pemrogramman yang bersifat Case Sensitive untuk nama identifier yang dibuat oleh user (berupa variable, konstanta, fungsi dll), namun tidak Case Sensitive untuk identifier built-in dari PHP. ${ }^{[9]}$

\section{F. Android}

Android adalah sistem operasi untuk telepon seluler yang berbasiskan Linux. Android menyediakan platform terbuka bagi para pengembang untuk menciptakan aplikasi mereka sendiri sehingga dapat digunakan oleh bermacam-macam peranti bergerak. Yang dibutuhkan untuk memulai pemrograman Android adalah Android SDK (Software Development Kit) dan juga JDK (Java Development Kit) serta membutuhkan Java IDE yang digunakan untuk menuliskan coding Android, dan juga Emulator untuk menjalankan aplikasi yang telah dibuat. ${ }^{[2]}$

\section{G. Blackbox Testing}

Blackbox testing merupakan pengujian perangkat lunak dari segi spesifikasi fungsional tanpa menguji desain dan kode program. Pengujian dimaksudkan untuk mengetahui apakah fungsi-fungsi, masukkan, dan keluaran dari perangkat lunak sesuai dengan spesifikasi yang dibutuhkan. Pengujian blackbox dilakukan dengan membuat kasus uji yang bersifat mencoba semua fungsi 
dengan memakai perangkat lunak apakah sudah sesuai dengan spesifikasi yang dibutuhkan. ${ }^{[7]}$

\section{Perancangan Sistem}

Untuk menyelesaikan tugas akhir ini, digunakan Software Development Life Cycle (SDLC) merupakan proses mengembangkan atau mengubah suatu sistem perangkat lunak dengan menggunakan model-model dan metodologi yang digunakan orang untuk mengembangkan sistem-sistem perangkat lunak sebelumnya. Salah satu model yang dimiliki oleh SDLC adalah teknik waterfall. Teknik waterfall menyediakan pendekatan alur hidup perangkat lunak secara terurut dimulai dari analisis, desain, pengodean, pengujian dan tahap pendukung ${ }^{[6]}$. Pada bab ini dijelaskan mengenai apa saja yang digunakan dalam pelaksanaan penelitian ini, dimana hasil akhirnya adalah aplikasi memantau lokasi anak berbasis Android yang dikembangkan menggunakan metode SDLC waterfall.

\section{A. Perancangan Sistem Aplikasi}

Dalam menggambarkan kebutuhan sistem digunakan Use Case Diagram. Untuk kebutuhan aplikasi dapat dilihat pada gambar 1 .

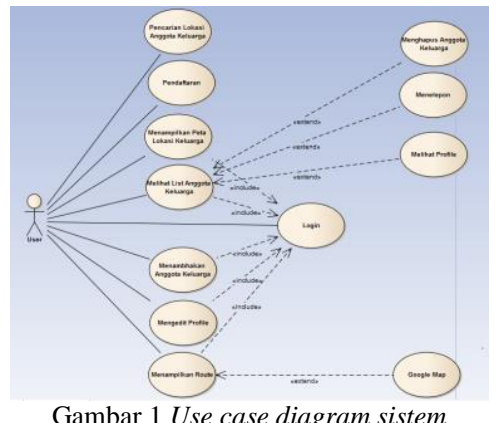

Pada gambar 1 dapat dilihat terdapat actor yaitu user, kemudian terdapat sebelas use case yaitu pendaftaran, menampilkan peta lokasi keluarga, mengedit profil, login, menambahkan anggota keluarga, pencarian lokasi anggota keluarga, menelepon, menghapus anggota keluarga, melihat profile anggota keluarga, melihat list anggota keluarga, dan menampilkan route

Untuk menggambarkan perilaku sistem serta aktifitas yang terjadi ketika sistem dijalankan. aktivitas serta perilaku aplikasi ini digambarkan dalam sepuluh diagram aktifitas yaitu activity diagram pendaftaran, activity diagram login, activity diagram melihat list anggota keluarga, activity diagram menambahkan anggota keluarga, activity diagram mengedit profil, activity diagram menampilkan route, activity diagram menghapus anggota keluarga, activity diagram menelepon, activity diagram pencarian lokasi anggota keluarga, dan activity diagram melihat profil. Seperti yang digambarkan pada gambar 2 sampai gambar 12,

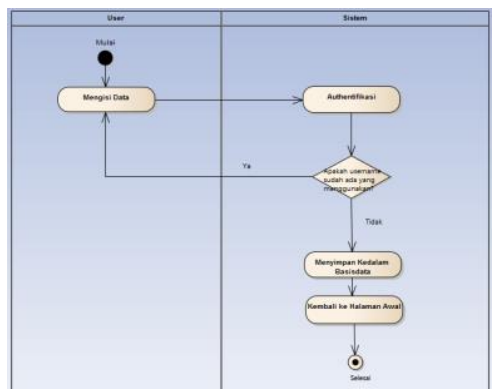

Gambar 2 Activity diagram pendaftran

Pada gambar 2 menggambarkan bagaimana proses user melakukan pembuatan akun baru.

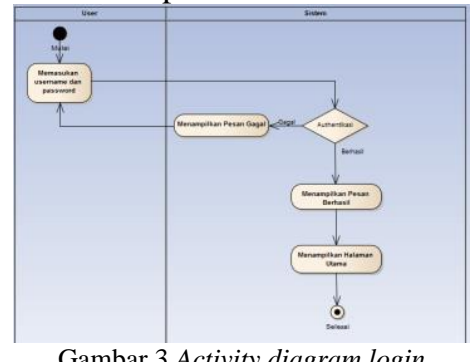

Pada gambar 3 menggambarkan proses ketika user melakukan login.

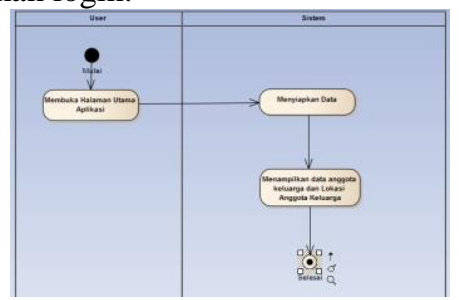

Gambar 4 Activity diagram menampilkan peta lokasi keluarga

Pada gambar 4 merupakan proses ketika menampilkan peta lokasi keluarga.

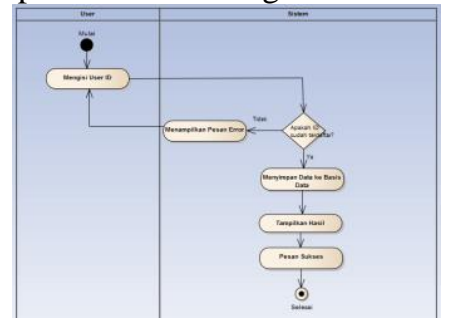

Gambar 5. Activity diagram menambahkan anggota keluarga

Gambar 5 merupakan proses dimana user melakukan penambahan anggota keluarga.

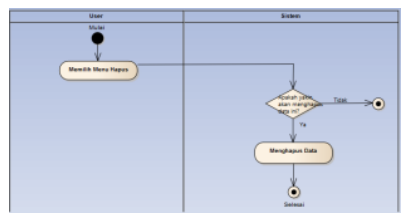

Gambar 6 Activity diagram menghapus anggota keluarga

Gambar 6 merupakan proses dimana user menghapus salah sat anggota keluargan

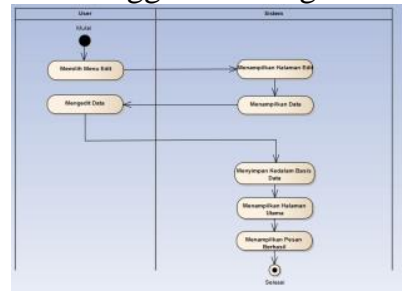


Gambar 7 Activity diagram mengedit profil

Pada gambar 7 menggambarkan proses ketika user akan melakukan perubahan identitas.

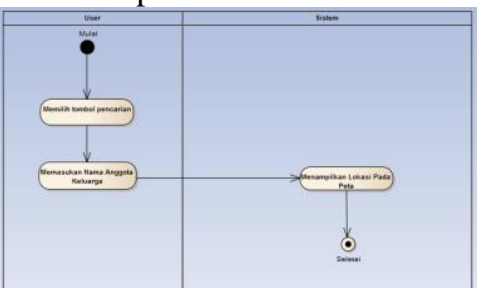

Gambar 8 Activity diagram pencarian lokasi anggota keluarga yang diinginkan

Gambar 8 menggambarkan proses ketika user melakukan proses pencarian lokasi salah satu anggota keluarga yang dituju.

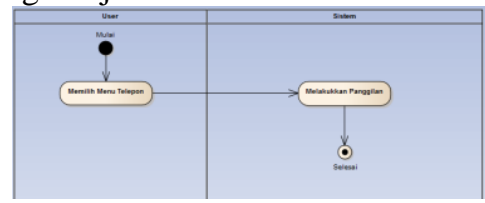

Gambar 9 Activity diagram telepon

Pada gambar 9 menggambarkan proses ketika user memilih menu telepon guna menelepon anggota keluarga yang dituju.

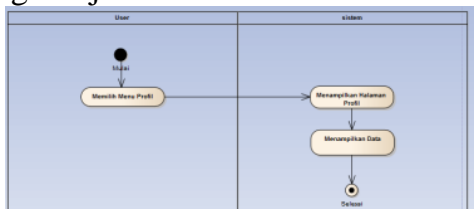

Gambar 10 Activity diagram profil anggota keluarga

Pada gambar 10 merupakan gambaran ketika user memilih menu profil, untuk mengetahui identitas salah satu anggota keluarga.

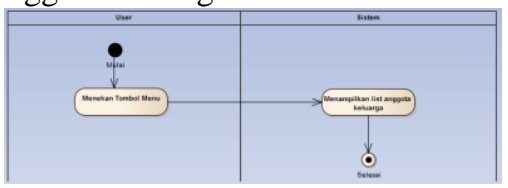

Gambar 11 Activity diagram melihat list anggota keluarga

Pada gambar 11 merupakan proses ketika user menekan tombol menu untuk melihat anggota keluarga yang telah terdaftar.

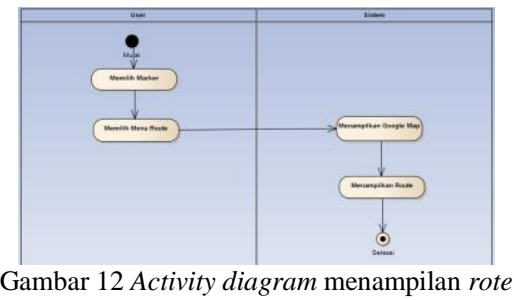

Gambar 12 merupakan proses ketika user memilih menu route, guna menampilkan route dari user ke salah satu anggota keluarga yang dituju.

\section{B. Perancangan Basisdata}

Pembuatan basis data dilakukan melalui localhost/phpmyadmin yang nantinya tabel akan diunggah kedalam web hosting. Penyimpanan data akan melibatkan tiga buah tabel, yaitu tabel tbl_user untuk menyimpan data pengguna, tabel tbl_lokasi untuk menyimpan lokasi pengguna, dan tabel tbl_keluarga untuk menyimpan data anggota keluarga. Untuk menggambarkan basisdata pada aplikasi ini dapat dilihat pada gambar 13 .

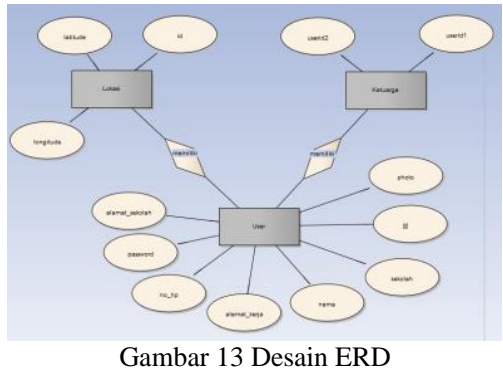

Dari desain yang telah dibuat dihasilkan sturktur tabel. Seperti yang terlihat pada tabel 1 sampai tabel 3 .

Tabel 1 Struktur tabel tbl_user

\begin{tabular}{|l|l|}
\hline \multicolumn{1}{|c|}{ Kolom } & \multicolumn{1}{c|}{ Tipe Data } \\
\hline$\underline{\mathrm{id}}$ & varchar(15) \\
\hline password & varchar(20) \\
\hline nama & varchar(30) \\
\hline no_hp & varchar(13) \\
\hline photo & longtext \\
\hline sekolah & varchar(50) \\
\hline alamat_sekolah & varchar(100) \\
\hline alamat_kerja & varchar(100) \\
\hline
\end{tabular}

.Tabel 2 Struktur tabel tbl_lokasi

\begin{tabular}{|l|l|}
\hline \multicolumn{1}{|c|}{ Kolom } & \multicolumn{1}{c|}{ Tipe Data } \\
\hline id & varchar $(15)$ \\
\hline latitude & decimal $(10,8)$ \\
\hline longitude & decimal $(11,8)$ \\
\hline
\end{tabular}

Tabel 3 Struktur tabel tbl_keluarga

\begin{tabular}{|l|l|}
\hline \multicolumn{1}{|c|}{ Kolom } & Tipe Data \\
\hline userid1 & varchar(15) \\
\hline userid2 & varchar(15) \\
\hline
\end{tabular}

\section{Perancangan Antarmuka}

Desain layout antarmuka merupakan tahapan yang dilakukan berikutnya, desain layout antarmuka bertujuan memberikan gambaran secara umum dari aplikasi yang akan dibangun. Desain layout antarmuka merupakan tahapan yang penting, karena ampilan akan berpengaruh terhadap pengguna baik dari segi kenyamanan serta kemudahan dalam penggunaan aplikasi. Seperti yang ditunjukan pada gambar 14 sampai gambar 20.

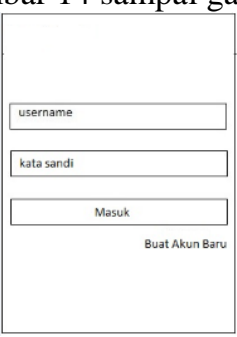

Gambar 14 Perancangan antarmuka halaman login 


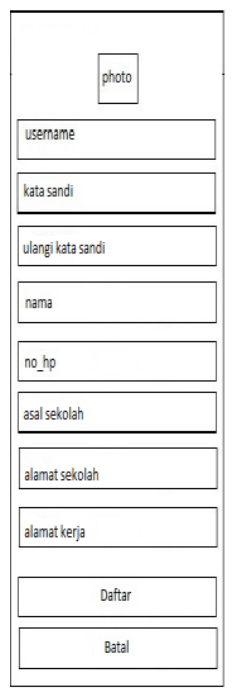

Gambar 15 Perancangan antarmuka halaman pendaftaran

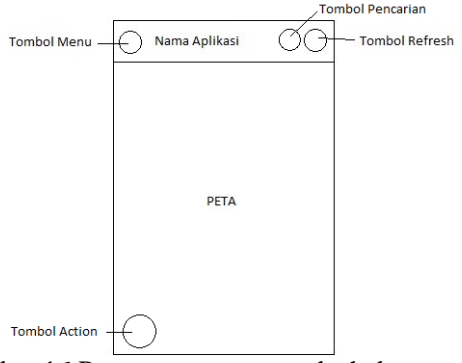

Gambar 16 Perancangan antarmuka halaman utama

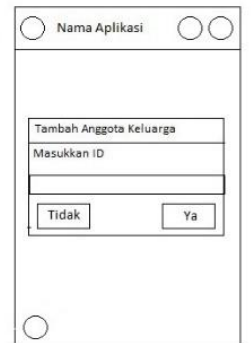

Gambar 17 Perancangan antarmuka pop-up tambah keluarga

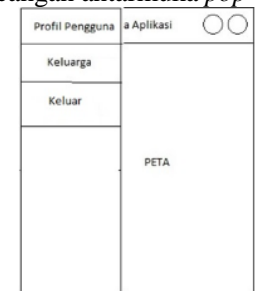

Gamabr 18 Perancangan antarmuka slidebar menu

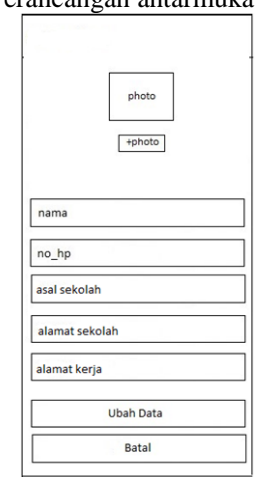

Gambar 19 Perancangan antarmuka halaman edit profile

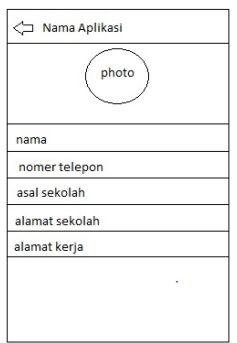

Gambar 20 Perancangan antarmuka halaman profile

\section{IMPLEMENTASI DAN PENGUJIAN}

\section{A. Implementasi}

Tahap implementasi dan pengujian dilakukan secara.terurut berdasarakan kebutuhan dari sistem, tahap pertama yang dilakukan adalah pembuatan basisdata dilanjutkan dengan tahap pembuatan layout aplikasi.

1. Tahap Pembuatan Basisdata

Pembuatan basisdata dilakukan menggunakan aplikasi phpmyadmin. Phpmyadmin menyediakan layanan pembuatan basisdata secara GUI, dengn memilih beberapa pilihan basisdata sudah dapat dibuat. Phpmyadmin juga menyediakan menu SQL yang digunakan untuk mengeksekusi query langsung ke basisdata. Berikut merupakan salah satu query yang digunakan untuk membuat tabel tbl_user.

CREATE TABLE tbl user(

id varchar( 15 ) PRIMARY KEY, password varchar( 20 ) NOT NULL, nama varchar( 30 ) NOT NULL no hp varchar( 13 ) NOT NULL, photo longtext NOT NULL sekolah varchar(50) NULL, alamat_sekolah varchar(100) NULL, alamat_kerja varchar(100) NULL) ;

\section{Pembuatan Aplikasi}

Pada pembuatan aplikasi yang pertama kali dilakukan adalah membuat halaman login. Halaman ini merupakan halaman awal ketika pengguna mulai menjalankan aplikasi. Tampilan halaman login ketika aplikasi dijalankan ditunjukkan pada gambar 21

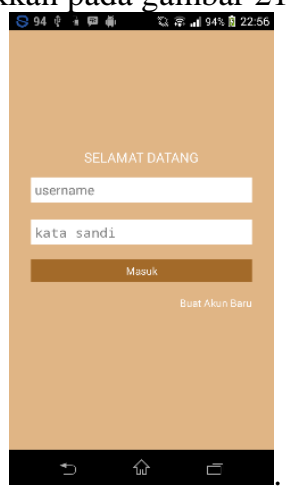

Gambar 21 Tampilan login aplikasi

Tahap selanjutnya adalah membuat halaman pendaftaran untuk pengguna baru. Halaman pendaftaran digunakan untuk membuat akun bagi pengguna yang nantinya akun tersebut digunakan sebagai akses untuk memasuki halaman utama dari aplikasi. Tampilan halaman pendaftaran ketika aplikasi ditunjukan pada Gambar 22. 


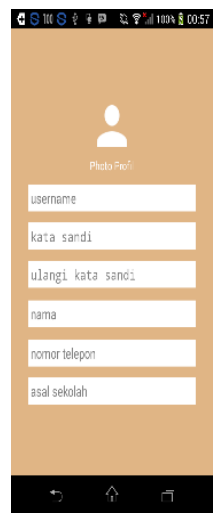

Gambar 22 Tampilan halaman pendaftaran

Tahap berikutnya membuat halaman utama dari aplikasi. Halaman utama digunakan untuk menampilkan posisi pengguna dan anggota keluarga yang sudah terdaftar. Tampilan halama utama ketika aplikasi dijalankan ditunjukan pada gambar 23.

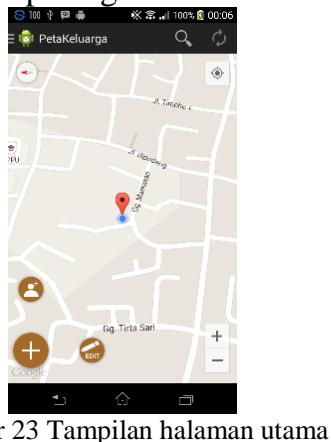

Gambar 23 Tampilan halaman utama

Tahap selanjutnya adalah pembuatan halaman ubah profil, pada halaman ini digunakan untuk mengubah data diri pengguna. Tampilan halaman ubah profil ketika aplikasi dijalankan ditunjukan pada gambar 24

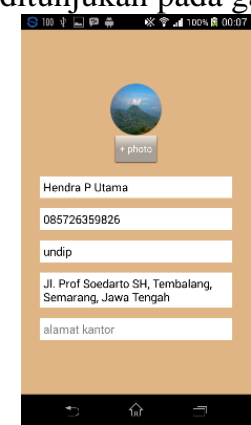

Gambar 24 Tampilan halaman edit profile

Selanjutnya adalah pembuatan halaman profil anggota keluarga, pada halaman ini digunakan untuk menampilkan identitas pengguna yang dituju. Tampilan halaman profil anggota keluarga ketika aplikasi dijalankan ditunjukan pada gambar 25.

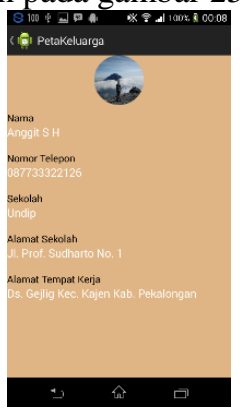

Gambar 25 Tampilan halaman profil
Selanjutnya adalah pembuatan tampilan menambahkan anggota keluarga kedalam list. Tampilan menambahkan anggota keluarga ketika aplikasi dijalankan ditujukan pada gambar 26.

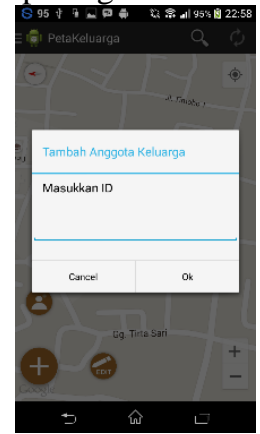

Gambar 26 Tampilan menambhakan anggota keluarga

Berikutnya adalah pembuatan tampilan menu untuk melihat list anggota keluarga. Tampilan menu ketika aplikasi dijalankan dapat dilihat pada gambar 27.

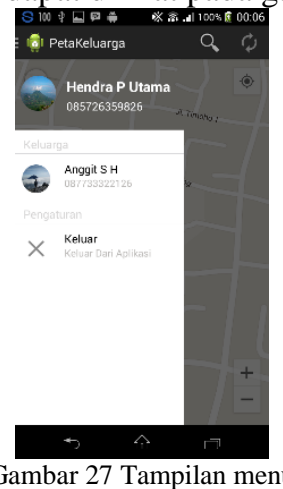

Tampilan menampilkan rute posisi pengguna ke posisi anggota keluarga ketika aplikasi dijalankan dapat dilihat pada gambar 28 .

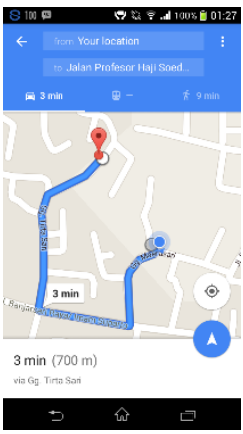

Gambar 28 Tamplan rute posisi pengguna ke posisi anggota keluarga

\section{B. Pengujian}

Pengujian dilakukan dengan menggunakan metode black-box. Pengujian ditekankan pada fungsional dari aplikasi. Tahap ini berisi serangkaian pengujian fungsi dan tombol dari aplikasi. Hasil dari pengujian dapat dilihat pada tabel 4 .

Tabel 4 Hasil pengujian black-box

\begin{tabular}{|l|l|l|c|}
\hline $\begin{array}{c}\text { Fungsi Yang } \\
\text { Diuji }\end{array}$ & Kondisi Awal & $\begin{array}{l}\text { Kondisi Akhir Yang } \\
\text { Diharapkan }\end{array}$ & $\begin{array}{c}\text { Hasil } \\
\text { Pengujia } \\
\mathrm{n}\end{array}$ \\
\hline $\begin{array}{l}\text { Pengujian } \\
\text { Aplikasi }\end{array}$ & $\begin{array}{l}\text { Pengguna } \\
\text { belum } \\
\text { menjalankan } \\
\text { aplikasi }\end{array}$ & $\begin{array}{l}\text { Masuk ke Aplikasi } \\
\text { dan menampilkan } \\
\text { halaman awal. }\end{array}$ & Berhasil \\
\hline $\begin{array}{l}\text { Pengujian } \\
\text { Login }\end{array}$ & $\begin{array}{l}\text { Pengguna } \\
\text { berada pada } \\
\text { halaman awal }\end{array}$ & $\begin{array}{l}\text { Menuju halaman } \\
\text { utama ketika } \\
\text { berhasil login dan }\end{array}$ & Berhasil \\
\hline
\end{tabular}




\begin{tabular}{|c|c|c|c|}
\hline & & $\begin{array}{l}\text { tampil pesan error } \\
\text { ketika gagal login } \\
\text { data yang telah } \\
\text { diinput kedalam } \\
\text { textbox menjadi } \\
\text { kosong dan kembali } \\
\text { ke halaman login. }\end{array}$ & \\
\hline $\begin{array}{l}\text { Pengujian } \\
\text { Halaman } \\
\text { Utama }\end{array}$ & $\begin{array}{l}\text { Pengguna } \\
\text { berada pada } \\
\text { halaman } \\
\text { utama aplikasi }\end{array}$ & $\begin{array}{l}\text { Menampilkan peta } \\
\text { posisi pengguna dan } \\
\text { pngguna lain. } \\
\text { Menampilkan data. } \\
\text { Mengaktifkan GPS. } \\
\text { Meyimpan lokasi } \\
\text { pengguna kedalam } \\
\text { basisdata }\end{array}$ & Berhasil \\
\hline $\begin{array}{l}\text { Pengujian } \\
\text { Tombol } \\
\text { Refresh }\end{array}$ & $\begin{array}{l}\text { Pengguna } \\
\text { berada pada } \\
\text { halaman } \\
\text { utama }\end{array}$ & $\begin{array}{l}\text { Menampilkan data } \\
\text { terbau }\end{array}$ & Berhasil \\
\hline $\begin{array}{l}\text { Pengujian } \\
\text { Tombol Menu }\end{array}$ & $\begin{array}{l}\text { Pengguna } \\
\text { berada pada } \\
\text { halaman } \\
\text { utama }\end{array}$ & $\begin{array}{l}\text { Menampilkan list } \\
\text { anggota keluarga } \\
\text { dan tmbol keluar }\end{array}$ & Berhasil \\
\hline $\begin{array}{l}\text { Pengujian } \\
\text { Tombol Route }\end{array}$ & $\begin{array}{l}\text { Pengguna } \\
\text { berada pada } \\
\text { halaman } \\
\text { utama dan } \\
\text { menekan salah } \\
\text { satu marker } \\
\text { yang terdapat } \\
\text { pada peta }\end{array}$ & $\begin{array}{l}\text { Sistem } \\
\text { menampilkan } \\
\text { navigasi } \\
\text { poute dari } \\
\text { posisi pengguna ke } \\
\text { posisi anggota } \\
\text { keluarga yang } \\
\text { diinginkan }\end{array}$ & Berhasil \\
\hline $\begin{array}{l}\text { Pengujian } \\
\text { Tombol Ubah } \\
\text { Profile }\end{array}$ & $\begin{array}{l}\text { Pengguna } \\
\text { berada pada } \\
\text { halaman } \\
\text { utama }\end{array}$ & $\begin{array}{l}\text { Menuju halaman } \\
\text { ubah profile }\end{array}$ & Berhasil \\
\hline $\begin{array}{l}\text { Pengujian } \\
\text { Tombol } \\
\text { Tambah }\end{array}$ & $\begin{array}{l}\text { Pengguna } \\
\text { berada pada } \\
\text { halaman } \\
\text { utama }\end{array}$ & $\begin{array}{l}\text { Memasukan ID } \\
\text { yang ingin } \\
\text { ditambahkan } \\
\text { Menyimpan data } \\
\text { kedalam basisdata. }\end{array}$ & Berhasil \\
\hline $\begin{array}{l}\text { Pengujian } \\
\text { Tombol Ubah } \\
\text { Data }\end{array}$ & $\begin{array}{l}\text { Pengguna } \\
\text { berada pada } \\
\text { halaman ubah } \\
\text { profile }\end{array}$ & $\begin{array}{l}\text { Menyimpan data } \\
\text { yang telah dirubah } \\
\text { kedalam basisdata }\end{array}$ & Berhasil \\
\hline $\begin{array}{l}\text { Pengujian } \\
\text { Tombol Batal }\end{array}$ & $\begin{array}{l}\text { Pengguna } \\
\text { berada pada } \\
\text { halaman ubah } \\
\text { profil }\end{array}$ & $\begin{array}{l}\text { Batal mengubah } \\
\text { data dan kembali ke } \\
\text { halaman utama }\end{array}$ & Berhasil \\
\hline $\begin{array}{l}\text { Pengujian } \\
\text { Tombol } \\
\text { Keluar }\end{array}$ & $\begin{array}{l}\text { Pengguna } \\
\text { berada pada } \\
\text { halaman } \\
\text { utama }\end{array}$ & Keluar dari Aplikasi & Berhasil \\
\hline Session & $\begin{array}{l}\text { Pengguna } \\
\text { telah keluar } \\
\text { dari aplikasi } \\
\text { tanpa } \\
\text { menekan } \\
\text { tombol keluar }\end{array}$ & $\begin{array}{l}\text { Masuk ke aplikasi } \\
\text { dan langsung } \\
\text { menuju halaman } \\
\text { utama tanpa melalui } \\
\text { halaman login }\end{array}$ & Berhasil \\
\hline Timer & $\begin{array}{l}\text { Pengguna } \\
\text { berada pada } \\
\text { halaman } \\
\text { utama atau } \\
\text { telah keluar } \\
\text { dari aplikasi }\end{array}$ & $\begin{array}{l}\text { Menyimpan posisi } \\
\text { pengguna kedalam } \\
\text { basisdata setiap } 10 \\
\text { menit }\end{array}$ & Berhasil \\
\hline
\end{tabular}

\section{Penutur}

\section{A. Kesimpulan}

Berdasarkan hasil pengujian dan analisis pembuatan aplikasi dapat disimpulkan sebagai berikut :

1. Aplikasi yang dibuat pada tugas akhir ini dapat menampilkan lokasi pengguna dan juga anggota keluarga terutama anak, sehingga orang tua yang menggunakan aplikasi ini dapat melihat lokasi anak mereka saat ini.

2. Berdasarkan pengujian yang dilakukan, aplikasi yang dibuat pada tugas akhir ini dapat dapat dijalankan pada perangkat bergerak dengan sistem operasi android versi Jelly Bean dan Lollipop.

3. Pada tugas akhir ini pembuatan aplikasi menggunakan eclipse.

4. Aplikasi yang dibuat pada tugas akhir ini membutuhkan koneksi internet dan GPS untuk menampilkan posisi pengguna.

\section{B. Saran}

Berdasarkan pengujian dan analisis terhadap aplikasi memantau lokasi anak berbasis android menggunakan location based service yang telah dibuat, penulis memberikan beberapa saran untuk pengembangan aplikasi dikemudian hari.

1. Penambahan fitur location history untuk menampilkan lokasi-lokasi yang telah dilalui kemarin.

2. Penambahan fitur lupa password untuk pengguna.

3. Pengembangan aplikasi agar dapat dijalankan pada berbagai platform, seperti iOS, Windows Phone, dan Blackberry.

\section{DAFTAR PUSTAKA}

[1] Anwar, Badrul dkk, "Implementasi Location Based Service Berbasis Android Untuk Mengetahui Posisi User", Jurnal SAINTKOM Vol.13, 2014.

[2] Ardiansyah, F., "Pengenalan Dasar Android". Depok: Biraynara, 2011.

[3] B. McLaughlin, PHP \& MySQL: The Missing Manual. 2012.

[4] Murtiwiyati and G. Lauren, "Rancang Bangun Aplikasi Pembelajaran Budaya Indonesia Untuk Anak Sekolah Dasar berbasis Android," J. Ilm., vol. 12, 2013.

[5] Noor, F.,2009, "Pengembangan Sistem Informasi Pemesanan Tiket Secara Online Pada P.O Bhinneka Sangkuriang Bandung”, Skripsi, Universitas Komputer Indonesia, Bandung.

[6] Rompas, B.R "Aplikasi Location Based Service Pencarian Tempat Di Kota Manado Berbasis Android”, Jurnal Teknik Elektro Dan Komputer Universitas Sam Ratulangi Vol. 1, 2012.

[7] Rosa, A.S. dan Shalahuddin, "Rekayasa Perangkat Lunak". Bandung: Modula, 2011.

[8] Satoto, B.D. dan Rahmanita, E., "Integrasi Augmented Reality pada Mobile Virtual Tour Berbasis Android untuk Pencarian Lokasi dan Rute Terdekat”, Jurnal Ilmiah Mikrotek Vol.1 No.1, 2013.

[9] Solichin, A., "MySQL 5: Dari Pemula Hingga Mahir". Jakarta: Universitas Budi Luhur, 2010

[10] Solichin, A., "Pemrograman Web dengan PHP dan MySQL". Jakarta: Univ. Budi Luhur, 2005.

[11] Utama, G., "Cara Efektif Menguasai Java", IlmuKomputer.com, 2002. 